7. Reprod. Fert. (1971) 27, 153-156

\title{
THE RELATION OF THE PROTEOLYTIC ACTIVITY OF HUMAN SEMINAL PLASMA TO VARIOUS SEMEN CHARACTERISTICS
}

\author{
J. SUOMINEN, R. ELIASSON AND M. NIEMI \\ Department of Anatomy, University of Turku, Finland, and \\ Department of Physiology I, Karolinska Institutet, Sweden
}

(Received 24th May 1971)

\begin{abstract}
Summary. Proteolytic activity, acid phosphatase activity and fructose concentration were measured in seminal plasma from 205 human semen samples. Certain routine sperm characteristics were also determined. High fibrinolytic activity was found and TAME-esterase and proteinase activity was also present in all specimens. The activity of all the proteolytic enzymes correlated positively with the acid phosphatase activity suggesting the prostate gland to be the origin of the enzymes. TAMEesterase activity was inversely related to the seminal fructose content. No correlation was observed between sperm characteristics and the seminal proteolytic enzymes. The specimens with abnormal viscosity usually contained low proteinase activity.
\end{abstract}

Human seminal plasma is known to possess considerable proteolytic activity; two protein-splitting enzymes have been found, one active at an acid $\mathrm{pH}$ and the other having similarities to chymotrypsin (Lundquist, Thorsteinsson \& Buus, 1955), Several investigators have demonstrated the presence of plasminogen activator(s) in seminal plasma (Lundquist et al. 1955; Rasmussen \& Albrechtsen, 1960; Hisazumi, 1970). Lundquist et al. (1955) also discovered an enzyme system in human seminal plasma, which hydrolyses arginine esters. Suominen \& Niemi (1970) have shown that this activity represents that of several different enzymes, e.g. the plasminogen activators. The function of these proteolytic enzymes is usually thought to be concerned with the liquefaction of the semen coagulum after ejaculation.

The purpose of the present study was to measure the total activity of proteinase, arginine-esterases and fibrinolytic enzymes in human seminal plasma, and to find out whether there is any correlation between these activities and certain parameters of accessory sex gland function (e.g. the activity of acid phosphatase for the prostate gland and the fructose content for the seminal vesicles) or other semen characteristics.

Semen samples were obtained from 205 patients who were being examined for infertility or for suspected disease of the accessory genital organs. The semen volume and viscosity, and the sperm density, motility, viability and morphology were analysed as described by Eliasson (1971). The following 
criteria for a normal semen specimen were used: concentration of spermatozoa $50 \times 10^{6} / \mathrm{ml}$ or more, $50 \%$ or more of the spermatozoa having normal motility and morphology, viscosity 5 sec or less (viscosity was estimated by measuring the time taken for semen to flow through a standard glass capillary chosen so that water flowed through it in $1 \mathrm{sec}$ ) and semen volume 2 to $6 \mathrm{ml}$.

Cell-free seminal plasma was obtained by centrifugation at $2800 \mathrm{~g}$ for $20 \mathrm{~min}$. Before the measurement of enzyme activity, the seminal plasma was diluted 1:8 with normal saline. All the measurements were made in duplicate at $+37^{\circ} \mathrm{C}, 0.1 \mathrm{M}$-tris-HCl buffer was used throughout. Proteinase activity was determined using casein $(10 \mathrm{mg} / \mathrm{ml})$ as a substrate at $\mathrm{pH} 7 \cdot 5$, the incubation time was $2 \mathrm{hr}$. Hydrolysis products were estimated according to Folin \& Ciocalteau (1927). The hydrolysis of TAME (p-toluene-sulphonyl-L-arginine methyl ester; $5 \mathrm{mmol} /$ litre) was determined according to Kabakoff, Umhey, Wohlman \& Avakian (1963), the incubation time was $4 \mathrm{hr}$. Fibrinolytic activity was measured using the fibrin-plate method presented by Brakman (1967),

TABLE 1

PROTEOLYTIC ACTIVITY IN NORMAL SEMEN SAMPLES

\begin{tabular}{|c|c|c|c|c|}
\hline & $\begin{array}{c}\text { Proteinase } \\
(\mu \mathrm{mol} / \mathrm{ml} / \mathrm{hr})^{*}\end{array}$ & $\begin{array}{c}\text { TAME-esterase } \\
\text { at } p H 7 \cdot 0 \\
(\mu m o l / m l / h r)\end{array}$ & $\begin{array}{c}\text { TAME-esterase } \\
\text { at pH } 8 \cdot 2 \\
(\mu \mathrm{mol} / \mathrm{ml} / \mathrm{hr})\end{array}$ & $\begin{array}{c}\text { Plasminogen } \\
\text { activators } \\
\left(\mathrm{mm}^{2}\right) \dagger\end{array}$ \\
\hline $\begin{array}{l}\text { Mean } \pm \text { S.E.M. } \\
\text { Range }\end{array}$ & $\begin{array}{c}3.06 \pm 0.22 \\
0.63 \text { to } 6.49\end{array}$ & $\begin{array}{c}4.33 \pm 0.34 \\
1.08 \text { to } 9.27\end{array}$ & $\begin{array}{c}7.50 \pm 0.51 \\
2 \cdot 47 \text { to } 13.65\end{array}$ & $\begin{array}{c}293 \pm 16 \\
185 \text { to } 583\end{array}$ \\
\hline No. & 28 & 28 & 28 & 28 \\
\hline
\end{tabular}

* L-Tyrosine equivalents.

$\dagger$ Lysis area by $30 \mu 1$ of the diluted seminal sample.

incubation time was $18 \mathrm{hr}$; plasminogen-rich fibrinogen (Grade B 1, Kabi, Sweden) was used and for plasmin assay the plasminogen was destroyed by heat. Acid phosphatase activity (i.u./ml) was assayed according to Sigma Bulletin No. 104 (normal values 25,000 to 60,000 i.u./ml). The fructose content of the seminal plasma (normal values $>120 \mathrm{mg} / 100 \mathrm{ml}$ ) was determined according to the methods described by Mann (1948) and Eliasson (1965).

There was a high fibrinolytic activity in human seminal plasma (Tables 1 to 3). Arginine-esterase and proteolytic activities were also present in all specimens. On the other hand, no lysis occurred on heated fibrin plates. The variation of the enzyme activities in semen samples that were classified as normal are given in Table 1. No marked differences were observed between the characteristics of the spermatozoa and the enzymes, e.g. there was no correlation between sperm morphology and motility and seminal proteolytic activity. When the samples were classified according to acid phosphatase activity (Groups 1 to 4, Table 2), there was a significant difference $(P<0.001)$ between the groups in proteinase and TAME-esterase activity. The correlation analysis confirmed also an interdependence between these activities and the acid phosphatase activity, the correlation coefficients were $0.70,0.59$ and 0.68 , respectively. A significant increase in the activity of the plasminogen activator was noted in connection with increased acid phosphatase activity. 
TABLE 2

THE RELATIONSHIP OF PROTEOLYTIC ACTIVITY OF SEMINAL PLASMA WITH PROSTATIC FUNCTION AS DETERMINED BY ACID PHOSPHATASE ACTIVITY OF SEMEN (MEAN \pm S.E.M., RANGE AND NUMBER OF SAMPLES)

\begin{tabular}{|c|c|c|c|c|}
\hline & $\begin{array}{c}\text { Proteinase } \\
(\mu \mathrm{mol} / \mathrm{ml} / \mathrm{hr})\end{array}$ & $\begin{array}{c}\text { TAME-esterase } \\
\text { at pH } 7.0 \\
(\mu \mathrm{mol} / \mathrm{ml} / \mathrm{hr})\end{array}$ & $\begin{array}{c}\text { TAME-esterase } \\
\text { at pH } 8 \cdot 2 \\
(\mu \mathrm{mol} / \mathrm{ml} / \mathrm{hr})\end{array}$ & $\begin{array}{c}\text { Plasminogen } \\
\text { activators } \\
\left(m m^{2}\right)\end{array}$ \\
\hline $\begin{array}{l}\text { Group I } \\
\text { (phosphatase } \\
0 \text { to } 9900 \mathrm{i} . \mathrm{u} . / \mathrm{ml} \text { ) }\end{array}$ & $\begin{array}{c}0.86 \pm 0.11 \\
0.12 \text { to } 1.51 \\
17\end{array}$ & $\begin{array}{c}2.65 \pm 0.39 \\
0.46 \text { to } 5.22 \\
17\end{array}$ & $\begin{array}{c}3.49 \pm 0.54 \\
0.29 \text { to } 8.34 \\
17\end{array}$ & $\begin{array}{c}244 \pm 17 \\
148 \text { to } 451 \\
17\end{array}$ \\
\hline $\begin{array}{l}\text { Group } 2 \\
\text { (phosphatase } \\
10,000 \text { to } 24,900 \mathrm{i} . \mathrm{u} . / \mathrm{ml} \text { ) }\end{array}$ & $\begin{array}{c}1 \cdot 74 \pm 0 \cdot 10 \\
0.45 \text { to } 4 \cdot 11 \\
68\end{array}$ & $\begin{array}{c}3.09 \pm 0.22 \\
0.63 \text { to } 10.98 \\
69\end{array}$ & $\begin{array}{c}5 \cdot 16 \pm 0.32 \\
1.66 \text { to } 15 \cdot 88 \\
69\end{array}$ & $\begin{array}{c}277 \pm 9 \\
135 \text { to } 514 \\
69\end{array}$ \\
\hline $\begin{array}{l}\text { Group 3 } \\
\text { (phosphatase } \\
25,000 \text { to } 59,900 \text { i.u./ml) }\end{array}$ & $\begin{array}{c}2.97 \pm 0.12 \\
0.63 \text { to } 6.49 \\
79\end{array}$ & $\begin{array}{c}4.16 \pm 0.20 \\
0.57 \text { to } 9.27 \\
81\end{array}$ & $\begin{array}{c}7.23 \pm 0.32 \\
2.23 \text { to } 17.99 \\
81\end{array}$ & $\begin{array}{c}307 \pm 9 \\
171 \text { to } 583 \\
81\end{array}$ \\
\hline $\begin{array}{l}\text { Group } 4 \\
\text { (phosphatase } \\
60,000 \text { or more i.u./ml) }\end{array}$ & $\begin{array}{c}4 \cdot 18 \pm 0.22 \\
2 \cdot 02 \text { to } 7 \cdot 28 \\
30\end{array}$ & $\begin{array}{c}8 \cdot 28 \pm 1 \cdot 04 \\
2 \cdot 46 \text { to } 31 \cdot 71 \\
30\end{array}$ & $\begin{array}{c}13 \cdot 49 \pm 1 \cdot 17 \\
6.00 \text { to } 33.69 \\
30\end{array}$ & $\begin{array}{c}337 \pm 24 \\
159 \text { to } 669 \\
30\end{array}$ \\
\hline
\end{tabular}

TABLE 3

THE RELATIONSHIP OF PROTEOLYTIC ACTIVITY OF SEMINAL PLASMA WITH THE FUNCTION OF THE SEMINAL VESICLES AS DETERMINED BY FRUCTOSE CONTENT OF SEMEN (MEAN \pm S.E.M., RANGE AND NUMBER OF SAMPLES)

\begin{tabular}{|c|c|c|c|c|}
\hline & $\begin{array}{c}\text { Proteinase } \\
(\mu \mathrm{mol} / \mathrm{ml} / \mathrm{hr})\end{array}$ & $\begin{array}{c}\text { TAME-esterase } \\
\text { at pH } 7 \cdot 0 \\
(\mu \mathrm{mol} / \mathrm{ml} / \mathrm{hr})\end{array}$ & $\begin{array}{c}\text { TAME-esterase } \\
\text { at pH } 8 \cdot 2 \\
(\mu \mathrm{mol} / \mathrm{ml} / \mathrm{hr})\end{array}$ & $\begin{array}{l}\text { Plasminogen } \\
\text { activators } \\
(\mu \mathrm{mol} / \mathrm{ml} / \mathrm{hr})\end{array}$ \\
\hline $\begin{array}{l}\text { Group } 5 \\
\text { (fructose } \\
0 \text { to } 120 \mathrm{mg} / 100 \mathrm{ml} \text { ) }\end{array}$ & $\begin{array}{c}3.34 \pm 0.34 \\
0.47 \text { to } 7.28 \\
27\end{array}$ & $\begin{array}{c}7.22 \pm 1 \cdot 13 \\
0.46 \text { to } 31 \cdot 71 \\
28\end{array}$ & $\begin{array}{c}11 \cdot 80 \pm 1.32 \\
3.71 \text { to } 33.69 \\
28\end{array}$ & $\begin{array}{c}327 \pm 23 \\
191 \text { to } 669 \\
28\end{array}$ \\
\hline $\begin{array}{l}\text { Group } 6 \\
\text { (fructose } \\
130 \text { to } 440 \mathrm{mg} / 100 \mathrm{ml} \text { ) }\end{array}$ & $\begin{array}{c}2 \cdot 41 \pm 0 \cdot 10 \\
0 \cdot 12 \text { to } 6 \cdot 49 \\
151\end{array}$ & $\begin{array}{c}3.96 \pm 0.20 \\
0.57 \text { to } 14.27 \\
153\end{array}$ & $\begin{array}{c}6.57 \pm 0.30 \\
0.29 \text { to } 22 \cdot 44 \\
153\end{array}$ & $\begin{array}{c}292 \pm 6 \\
148 \text { to } 583 \\
153\end{array}$ \\
\hline $\begin{array}{l}\text { Group } 7 \\
\text { (fructose } \\
450 \text { or more } \mathrm{mg} / 100 \mathrm{ml} \text { ) }\end{array}$ & $\begin{array}{c}2 \cdot 53 \pm 0 \cdot 39 \\
0 \cdot 83 \text { to } 6 \cdot 13 \\
18\end{array}$ & $\begin{array}{c}3.01 \pm 0.27 \\
I .48 \text { to } 6.08 \\
18\end{array}$ & $\begin{array}{c}5 \cdot 57 \pm 0 \cdot 66 \\
2 \cdot 51 \text { to } 12 \cdot 15 \\
18\end{array}$ & $\begin{array}{c}293 \pm 25 \\
135 \text { to } 514 \\
18\end{array}$ \\
\hline
\end{tabular}


When the semen samples were classified according to the seminal fructose content (Groups 5 to 7 , Table 3 ), a significant difference $(P<0.05)$ in the TAME-esterase activities was noted between the groups, indicating decreased esterase activity with increased fructose content. The correlation coefficients were -0.37 and -0.40 . The proteinase and plasminogen activator activities were negatively correlated with the seminal fructose content, the correlation being, however, clearly less than that between TAME-esterases and fructose. When the enzyme activities were compared with the semen viscosity, the proteinase activity was significantly lower in the group with abnormally high viscosity.

The prostate gland and the seminal vesicles secrete several chemical constituents into the semen, some of which can be considered as specific for the glands, e.g. acid phosphatase for the prostate and fructose for the seminal vesicles (Mann, 1964). All the enzyme activities correlated significantly with the acid phosphatase activity, which can be taken to indicate a prostatic origin for the proteases. A reverse correlation between TAME-esterase activity and fructose content and, to a lesser extent, between the other proteolytic enzymes and fructose content was noticed. This could be due to reduced enzyme activity following dilution when there was a higher proportion of seminal vesicle secretion in the semen. However, it is more likely that the seminal vesicles secrete some substance which inhibits the TAME-esterases and, to a lesser extent, the other proteolytic enzymes. It has been suggested that high viscosity of the semen might be a cause of decreased fertility (Amelar, 1966). In the present study, we observed that high semen viscosity was usually associated with low proteinase activity which may indicate that this proteolytic enzyme can be involved in human fertility.

This work was supported by grants from The Population Council, New York, and the Swedish Medical Research Council (14x-538). Research material for the fibrinolytic method was kindly given by AB Kabi, Sweden.

\section{REFERENCES}

Amelar, R. D. (1966) Infertility in men, p. 108. Davis, Philadelphia.

Brakman, P. (1967) Fibrinolysis. A standardized fibrin plate method and a fibrinolytic assay of plasminogen. Scheltema \& Hokema, Amsterdam.

Eliasson, R. (1965) Effect of frequent ejaculations on the composition of the human seminal plasma. F. Reprod. Fert. 9, 331.

Eliasson, R. (1971) Standards for investigation of human semen. Andrologie, 3, 49.

Folin, O. \& Crocalteau, U. (1927) On tyrosine and tryptophane determinations in proteins. $\mathcal{F}$. biol. Chem. 123, 627.

Hisazumi, H. (1970) Studies on the fibrinolytic activity in human semen studied by gel filtration. Invest. Urol. $7,410$.

Kabakoff, B. L., Umhey, M., Wohlman, A. \& Avakian, S. (1963) Sensitive and reproducible assay method for chymotrypsin. F. pharmac. Sci. 52, 1188.

Lundquist, F., Thorsteinsson, T. \& Buus, O. (1955) Purification and properties of some enzymes in human seminal plasma. Biochem. F. 59, 69.

MaNN, T. (1948) Fructose and fructolysis in semen in relation to fertility. Lancet, i, 446.

MANN, T. (1964) The biochemistry of semen and the male reproductive tract, 2nd edn, pp. 43 and 51 . Methuen, London.

Rasmussen, J. \& Albrechtsen, O. K. (1960) Fibrinolytic activity in human seminal plasma. Fert. Steril. 11. 264.

Stominen, J. \& Niemi, M. (1970) Proteolytic enzymes in human seminal fluid. Scand. f. clin. Lab. Invest. 25, Suppl. 113, 52. 